\title{
PATTERNS OF TRACE-ELEMENT DISTRIBUTION IN CALCIC AMPHIBOLES AS A FUNCTION OF METAMORPHIC GRADE
}

\author{
SERGEY SKUBLOV§ AND GaLINA DRUGOVA \\ Institute of Precambrian Geology and Geochronology, emb. Makarova 2, St. Petersburg 199034, Russia
}

\begin{abstract}
The distribution of the rare earths and other trace elements in calcic amphiboles from the Njurundukan mafic complex, northwestern Baikal region, in Russia, depends on metamorphic grade. Both total $R E E$ and $\mathrm{La} / \mathrm{Yb}$ in amphiboles decrease with decreasing temperature of metamorphism. Consistent partition-coefficients for trace elements in amphibole and coexisting garnet, suggestive of equilibrium, are best developed in granulite-facies rocks. Such a consistent distribution of the REE is disturbed in amphibolite-facies rocks owing to incipient metasomatism. Amphiboles from metasomatic rocks show REE distributions that differ from those in amphiboles belonging to the metamorphic culmination, and commonly are inherited from precursor minerals. This property leads to the establishment of the sequence of mineral formation in metasomatically altered rocks. Comparison with amphiboles from the high-pressure Lapland granulite complex, Baltic Shield, suggests that pressure does not affect REE abundance and distribution in amphiboles.
\end{abstract}

Keywords: trace elements, rare-earth elements, calcic amphibole, Njurundukan mafic complex, Baikal, Russia.

\section{SOMMAIRE}

La distribution des terres rares et autres éléments traces dans les amphiboles calciques du complexe mafique de Njurundukan, dans le nord-ouest de la région de Baïkal, en Russie, dépend du degré de métamorphisme. La teneur en terres rares et le rapport $\mathrm{La} / \mathrm{Yb}$ des amphiboles diminuent à mesure que diminue la température du métamorphisme. Des coefficients de partage conséquents pour les éléments traces dans l'amphibole et le grenat coexistant, indications possible d'un équilibre, sont les mieux développés dans les roches sujettes à un métamorphisme dans le faciès granulite. Une telle distribution conséquente des terres rares est dérangée au cours d'épisodes de métamorphisme dans le faciès amphibolite à cause d'un début de métasomatose. Dans les amphiboles des roches métasomatiques, la distribution des terres rares diffère de celle des amphiboles développées menant à la culmination métamorphique; elle est apte à être héritée de minéraux précurseurs. Cette propriété mène à l'établissement d'une séquence de formation des minéraux dans des roches altérées par métasomatose. Une comparaison avec les amphiboles provenant du socle granulitique de haute pression en Lapponie, Bouclier Baltique, nous fait penser que la pression n'affecte pas l'abondance et la distribution des terres rares dans les amphiboles.

(Traduit par la Rédaction)

Mots-clés: éléments traces, terres rares, amphibole calcique, complexe mafique de Njurundukan, Baïkal, Russie.

\section{INTRODUCTION}

In spite of important advances in analytical techniques applied to the rock-forming minerals, there is very little information in the literature about distributions of the rare-earth elements (REE) in metamorphic calcic amphiboles; amphiboles from igneous rocks (e.g., Cortesogno et al. 2000, Zanetti et al. 1995) and eclogites (e.g., Sassi et al. 2000) are better understood. Only a few determinations of the REE in amphiboles from granulite-facies rocks have been reported (Loock et al. 1990, Pride \& Muecke 1981), and data on REE abun- dance in amphiboles from amphibolite-facies rocks are virtually absent (Kretz et al. 1999, Sorensen \& Grossman 1989).

In this article, we examine patterns of trace-element distribution, including the rare earths, in calcic amphiboles (hornblende) from the Njurundukan mafic metamorphic complex, northwestern Baikal region, in Russia, where amphibole crystallization took place over a wide range of pressure and temperature (Table 1). In addition, amphiboles from the Lapland granulite complex and metasomatic amphiboles from the Belomorian complex, in the Baltic Shield, were investigated.

§_E-mail address: skublov@ad.iggp.ras.spb.ru 


\section{Analytical Methods}

Trace-elements abundances in amphiboles were determined by the instrumental neutron activation method (INAA) at the Institute of Precambrian Geology and Geochronology, St. Petersburg. Amphibole grains were separated by use of a jaw crusher, a ceramic mortar and pestle, plastic sieves (to obtain particles in the size range $0.12-0.24 \mathrm{~mm}$ ), a Frantz magnetic separator, heavy liquids, and final removal of foreign particles using the tip of a needle.

One zoned amphibole was studied by secondary-ion mass spectrometry (SIMS) at the Institute of Microelectronics, Yaroslavl. A Cameca IMS-4F ion microprobe was used to determine REE concentrations. Information on the procedure is provided by Smirnov et al. (1995).

\section{Geological Setting and Metamorphism}

The Precambrian Njurundukan mafic complex in the northwestern Baikal region comprises tectonically jux- taposed of two-pyroxene garnet-free schists, first metamorphosed at the granulite facies $\left(770-850^{\circ} \mathrm{C}, 5-6\right.$ kbar), and repeatedly migmatized amphibolites and metagabbros (Skublov 1993). The age of the granulitefacies metamorphism was determined as $617 \mathrm{Ma}$ (Amelin et al. 2000). A low-pressure, high-temperature amphibolite-facies metamorphism $\left(650^{\circ} \mathrm{C}\right.$ and $4-5$ kbar) was superimposed on the entire Njurundukan complex except along the bordering Sljudanka shear zone (Fig. 1). The latter is situated at the contact of the complex with the low-grade Olokit complex, where mineral assemlages mark a transition to high pressures $\left(580^{\circ} \mathrm{C}\right.$ and $\left.9-10.5 \mathrm{kbar}\right)$. It is only within the Sljudanka shear zone that amphibolitized granulites, feldspathic amphibolites and metagabbros are transformed into garnet amphibolites, among which bodies of eclogite-type rocks are found. Retrograde metamorphism at $550^{\circ} \mathrm{C}$ and 6-7 kbar, accompanied by extensive metasomatism, were superimposed on the effects of high-pressure metamorphism.

TABLE 1. COMPOSITIONS OF METAMORPHIC AMPHIBOLE, AS DETERMINED BY ELECTRON-MICROPROBE AND INSTRUMENTAL NEUTRON-ACTIVATION ANALYSES

\begin{tabular}{|c|c|c|c|c|c|c|c|c|c|c|c|c|c|c|c|c|c|}
\hline & \multicolumn{2}{|c|}{ Kaersutite } & \multicolumn{6}{|c|}{ Granulite-grade amphibole } & \multicolumn{4}{|c|}{$\begin{array}{l}\text { High-T amphibolite- } \\
\text { grade amphibole } \\
\text { Green and brown-green } \\
\text { hornblende }\end{array}$} & \multicolumn{2}{|c|}{$\begin{array}{l}\text { Low-T amphibolite- } \\
\text { grade amphibole } \\
\text { Blue-green } \\
\text { hornblende }\end{array}$} & \multicolumn{3}{|c|}{$\begin{array}{l}\text { Metasomatic } \\
\text { amphibole } \\
\text { Blue-green } \\
\text { hornblende }\end{array}$} \\
\hline & $3 / 4$ & 411 & 483 & 522 & 632 & Lap-12 & Lap-13 & $\mathrm{C}-7$ & 487 & 499 & 23 & $54 / 3$ & $12 / 3$ & 75 & 133 & $14 \mathrm{~b}$ & $82 d$ \\
\hline $\mathrm{SiO}_{2}$ wt. $\%$ & 40.72 & 40.71 & 42.01 & 43.66 & 40.49 & 40.95 & 42.24 & 40.69 & 43.66 & 44.06 & 44.45 & 42.03 & 42.32 & 40.21 & 43.51 & 42.34 & 44.55 \\
\hline $\mathrm{TiO}_{2}$ & 4.83 & 5.52 & 2.12 & 1.88 & 1.99 & 2.43 & 2.38 & 2.17 & 1.70 & 1.29 & 0.91 & 1.46 & 0.34 & 0.51 & 0.69 & 0.79 & 0.41 \\
\hline $\mathrm{Al}_{2} \mathrm{O}_{3}$ & 13.62 & 13.17 & 11.12 & 11.00 & 13.23 & 11.60 & 13.41 & 11.87 & 9.77 & 10.62 & 14.11 & 13.13 & 15.04 & 19.17 & 15.46 & 17.89 & 15.86 \\
\hline $\mathrm{FeO}^{*}$ & 9.94 & 11.32 & 13.86 & 15.71 & 18.12 & 21.78 & 16.19 & 20.95 & 16.86 & 13.37 & 13.72 & 19.87 & 16.98 & 9.71 & 14.03 & 15.60 & 11.73 \\
\hline $\mathrm{MnO}$ & 0.13 & n.d. & 0.22 & n.d. & 0.21 & 0.19 & 0.22 & 0.16 & 0.36 & n.d. & n.d. & n.d. & n.d. & 0.03 & n.d. & 0.17 & 0.01 \\
\hline $\mathrm{MgO}$ & 12.71 & 12.06 & 13.43 & 11.28 & 9.35 & 6.50 & 9.18 & 8.01 & 11.17 & 13.49 & 11.52 & 7.07 & 9.51 & 13.60 & 11.44 & 9.81 & 12.36 \\
\hline $\mathrm{CaO}$ & 12.18 & 11.19 & 11.42 & 11.40 & 11.23 & 10.75 & 10.94 & 10.56 & 11.40 & 11.92 & 10.21 & 11.43 & 10.56 & 9.78 & 10.35 & 10.90 & 11.27 \\
\hline $\mathrm{Na}_{2} \mathrm{O}$ & 2.46 & 2.58 & 1.79 & 1.44 & 1.50 & 1.98 & 1.92 & 2.29 & 1.61 & 2.20 & 2.64 & 2.17 & 2.51 & 3.52 & 2.06 & n.d. & 0.72 \\
\hline $\mathrm{K}_{2} \mathrm{O}$ & 1.75 & 1.59 & 1.12 & 1.18 & 1.88 & 1.84 & 1.52 & 1.30 & 1.24 & 1.10 & 0.31 & 0.86 & 0.73 & 0.12 & 0.30 & 0.50 & n.d. \\
\hline Total & 98.34 & 98.14 & 97.09 & 97.55 & 98.00 & 98.00 & 98.00 & 98.00 & 97.77 & 98.05 & 97.87 & 98.02 & 97.99 & 96.65 & 97.84 & 98.00 & 96.91 \\
\hline La ppm & 11.7 & 29.6 & 54.6 & 25.6 & 30.2 & 30.3 & 18.3 & 8.3 & 6.3 & 2.9 & 2.6 & 2.3 & 2.0 & 1.9 & $<0.5$ & 1.3 & $<0.5$ \\
\hline $\mathrm{Ce}$ & 57.2 & 110 & 130 & 63.7 & 75.6 & 63.8 & 41.9 & 18.3 & 16.2 & 6.9 & 10.3 & 13.2 & 15.6 & 8.9 & $<5.0$ & $<5.0$ & $<5.0$ \\
\hline $\mathrm{Nd}$ & 62.3 & 86.2 & 71.3 & 43.6 & 59.7 & 41.4 & 28.1 & 9.5 & 12.5 & 6.8 & 16.8 & 9.8 & 14.5 & 9.2 & $<3.0$ & $<3.0$ & $<3.0$ \\
\hline $\mathrm{Sm}$ & 18.6 & 22.2 & 19.4 & 10.9 & 18.5 & 9.38 & 7.38 & 2.2 & 4.53 & 1.89 & 2.98 & 3.1 & 2.97 & 1.98 & 0.39 & 0.54 & 0.26 \\
\hline $\mathrm{Eu}$ & 5.65 & 5.88 & 5.4 & 2.95 & 3.85 & 2.4 & 1.94 & 0.78 & 1.57 & 1.00 & 0.74 & 0.52 & 1.61 & 0.76 & $<0.05$ & 0.58 & 0.13 \\
\hline $\mathrm{Tb}$ & 3.74 & 4.53 & 4.37 & 2.16 & 2.93 & 1.14 & 0.83 & 0.36 & 0.91 & 0.61 & 0.54 & 0.89 & 0.69 & 0.47 & 0.13 & 0.59 & 0.46 \\
\hline $\mathrm{Yb}$ & 10.0 & 12.4 & 13.2 & 6.28 & 12.2 & 4.06 & 2.81 & 0.8 & 3.93 & 2.65 & 2.2 & 1.77 & 2.8 & 2.00 & 1.47 & 9.15 & 2.32 \\
\hline $\mathrm{Lu}$ & 1.49 & 1.84 & 1.57 & 0.96 & 1.85 & 0.6 & 0.4 & 0.1 & 0.61 & 0.39 & 0.32 & 0.26 & 0.41 & 0.29 & 0.27 & 1.5 & 0.37 \\
\hline $\mathrm{Sc}$ & 83.8 & 81.1 & 81.9 & 56.2 & 82.5 & 52.9 & 53.1 & 58.3 & 71.7 & 57.6 & 51.9 & 69.7 & 71.1 & 50.1 & 54.6 & 79.5 & 68.7 \\
\hline $\mathrm{Cr}$ & 58 & 148 & 97 & 78 & 77 & $<5$ & 144 & 29 & 225 & 702 & 38 & 439 & 118 & $<10$ & 29 & 495 & 448 \\
\hline $\mathrm{Co}$ & 40.6 & 48.0 & 50.6 & 55.5 & 54.0 & 65.5 & 72.3 & 75.9 & 64.3 & 65.2 & 47.3 & 103.9 & 32.3 & 46.8 & 58.9 & 61.4 & 139.0 \\
\hline $\mathrm{Hf}$ & 5.1 & 6.5 & 3.8 & 4.0 & 3.8 & 5.1 & 3.1 & 3.0 & 2.0 & $<0.5$ & 0.72 & 3.6 & 1.8 & $<0.5$ & 1.0 & 1.9 & 2.1 \\
\hline $\mathrm{Ta}$ & 1.18 & 1.94 & 0.93 & 0.68 & 0.37 & 0.63 & 0.55 & 0.083 & 0.25 & 0.093 & 0.026 & 0.12 & 0.10 & 0.064 & $<0.01$ & 0.23 & 0.064 \\
\hline Total REE & 170.7 & 272.7 & 299.8 & 156.2 & 204.8 & 153.0 & 101.7 & 40.3 & 46.6 & 23.1 & 36.5 & 31.8 & 40.6 & 25.5 & $<10.8$ & $<21.7$ & $<12.0$ \\
\hline $\mathrm{La} / \mathrm{Yb}^{* *}$ & 0.79 & 1.62 & 2.81 & 2.77 & 1.68 & 5.07 & 4.42 & 7.05 & 1.09 & 0.74 & 0.80 & 0.88 & 0.49 & 0.65 & $<0.23$ & 0.10 & $<0.15$ \\
\hline
\end{tabular}

Amphibole from the Njurundukan complex (samples 3/4, 411, 483, 522, 487, 499, 23, 54/3, 12/3, 75, 133), the Lapland complex (samples 632 , Lap-12, Lap-13, C-7) and the Belomorian complex (samples 14b, 82d). * Total Fe as FeO. ** The ratio La/Yb is chondrite-normalized. n.d.: not detected. 
Calcic amphiboles are virtually ubiquitous in the Njurundukan complex, and thus important in unravelling the metamorphic history of the complex. These amphiboles are compared with hornblende from the Lapland granulite complex, which underwent metamorphism at a much higher pressure (up to 11-12 kbar). The petrology and mineralogy of rocks from the Lapland complex, including those used in this work, have been extensively treated by Perchuk et al. (1999) and Skublov et al. (2000). Metasomatic events in the Njurundukan rocks from the Sljudanka zone are difficult to distinguish from low-temperature regional metamorphic processes. In this connection, we also considered amphiboles from the Belomorian complex, whose origin is unambiguously metasomatic, as is clear from features such as structure, coarse texture, and composition of polymineralic rocks (Drugova et al. 1998). $\mathrm{P}-\mathrm{T}$ parameters of metasomatic amphiboles from the Belomorian complex are determined to be $500-600^{\circ} \mathrm{C}$ and 6-7 kbar (Drugova et al. 1998).

\section{Compositional Features of the Amphiboles}

Amphiboles presented in Table 1 are subdivided into two large groups, as a function of Ti content (Fig. 2): granulite-facies amphiboles and amphibolite-facies amphiboles. Two amphiboles from the Njurundukan two-pyroxene schists (samples 3/4, 411, Table 1) have

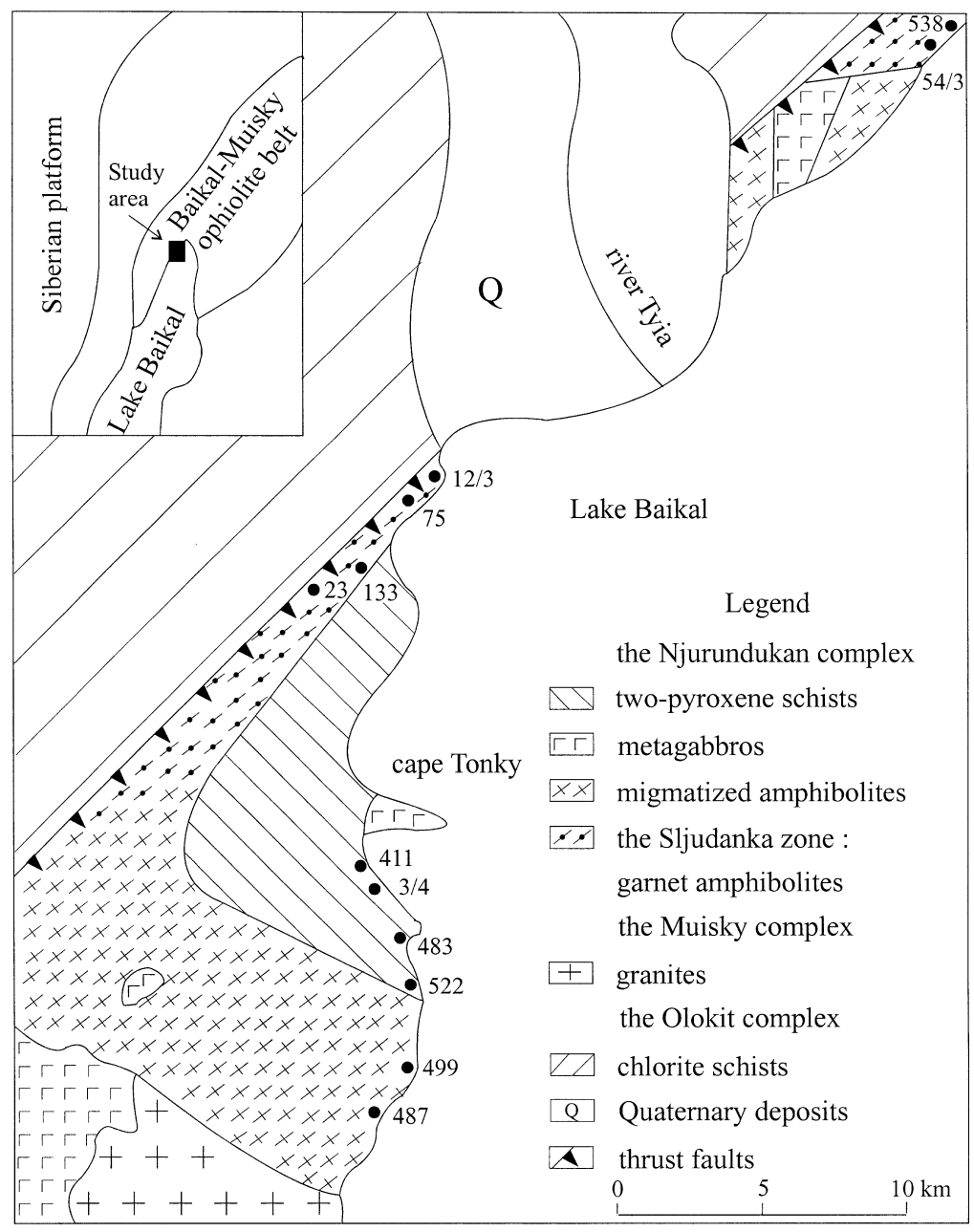

FIG. 1. Generalized geological map of the Njurundukan complex, showing sample locations. 
a very high Ti content, and are referred to as kaersutite, and seem to be relics of a magmatic protolith. Other amphiboles are referred to magnesiohornblende and ferrohornblende according to Leake et al. (1997). Figure 2 shows these amphiboles clearly separated from other granulite-facies amphiboles. The $\mathrm{TiO}_{2}$ level and the $\mathrm{Fe} /(\mathrm{Fe}+\mathrm{Mg})$ values permit discrimination between granulite- and amphibolite-facies amphiboles (Fig. 2). Titanium content is a useful parameter in semiquantitative geothermometry based on amphibole (e.g., Ernst \& Liu 1998). An appreciable decrease in Ti content is noted in going from the granulite-facies amphiboles to those of the high-temperature amphibolite facies and further, the low-temperature amphibolite-facies amphiboles and metasomatic amphiboles.

Two high-temperature amphibolite-facies amphiboles (samples 487, 499, Table 1) are derived from the main portion of the Njurundukan complex, where the effects of high-pressure metamorphism are absent. Two other samples from the same group (samples 23, 54/3), as well as all the low-temperature amphiboles and metasomatic amphibole (sample 133) are from high-pressure garnet amphibolite of the Sljudanka zone. Amphiboles from the high-pressure zone exhibit high Al content (indirectly indicative of increasing pressure according to Ernst \& Liu 1998), and higher $\mathrm{Na}$ than the granulitefacies amphiboles. Amphiboles from the Sljudanka zone

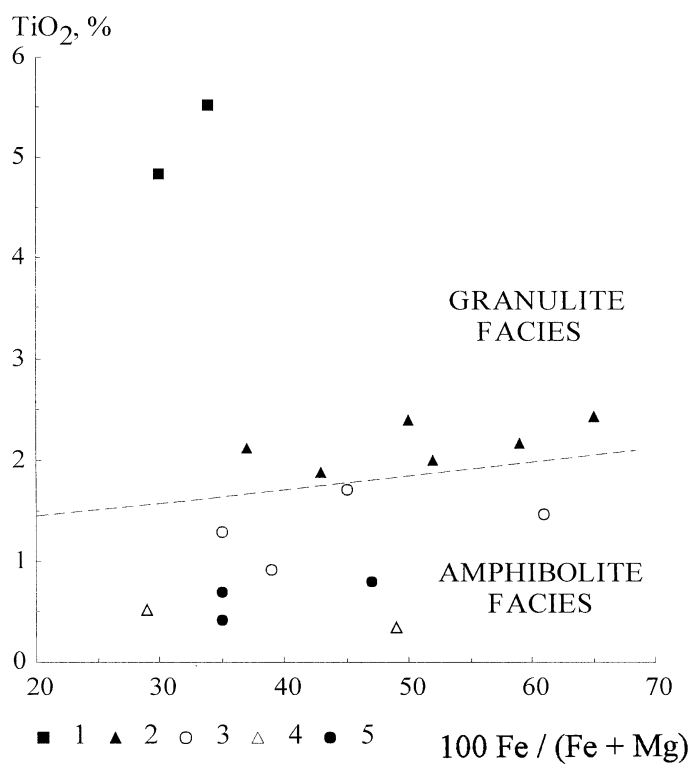

FIG. 2. $\mathrm{TiO}_{2}$ content versus $100 \mathrm{Fe} /(\mathrm{Fe}+\mathrm{Mg})$ value in amphiboles. Fields: I: granulite-facies amphiboles, II: amphibolite-facies amphiboles. Symbols here and in other figures are kaersutite (1), granulite-grade amphibole (2), high-T (3) and low-T (4) amphibolite-grade amphiboles, and metasomatic amphibole (5). have, in contrast, lower levels of $\mathrm{K}$ than do other amphiboles in the suite investigated.

Amphiboles from the Njurundukan complex show considerable variation in Fe content as a function of both the heterogeneous nature of the complex and host-rock composition $[\mathrm{Fe} /(\mathrm{Fe}+\mathrm{Mg})$ value] (Skublov 1993). Amphiboles from the Lapland complex are richer in iron than those from the Njurundukan complex. The amphibole groups also differ in trace-element abundances (Table 1). The behavior of $\mathrm{Cr}$ and Co shows an inconsistent pattern; their content in amphibole is as a rule highly dependent on host-rock composition (Drugova et al. 1998). A negative correlation of $\mathrm{Cr}$ and $\mathrm{Co}$ with $\mathrm{Na}$, and positive correlation of $\mathrm{Cr}$ with $\mathrm{Ca}$ in amphibole have been revealed. Low-pressure amphiboles usually show higher Sc than amphiboles from garnet-bearing assemblages. The temperature dependence of Sc is unclear, though a weakly positive correlation of Ti with $\mathrm{Sc}$ in amphiboles is observed (Table 1).

Apart from the REE (which will be considered below), the high field-strength elements (HFSE) Hf and Ta, proved to be most informative, as they enable us to distinguish granulite- and amphibolite-facies amphiboles (Fig. 3). The lowest Hf and Ta contents occur in low-temperature amphiboles, the highest in kaersutite. The abundance of these two elements in amphibole from the Sal'nye Tundry, Lapland complex (sample C-7, Table 1), indicates that despite the high $\mathrm{Ti}$, it resembles a lower-temperature amphibole. Petrographic evidence (the appearance of green spots in brown hornblende) and lower $\mathrm{Mg}$ content of coexisting garnet (Skublov et al. 2000) suggest incipient retrogression of the rock, which is reflected in the rare-element abundances in amphibole.

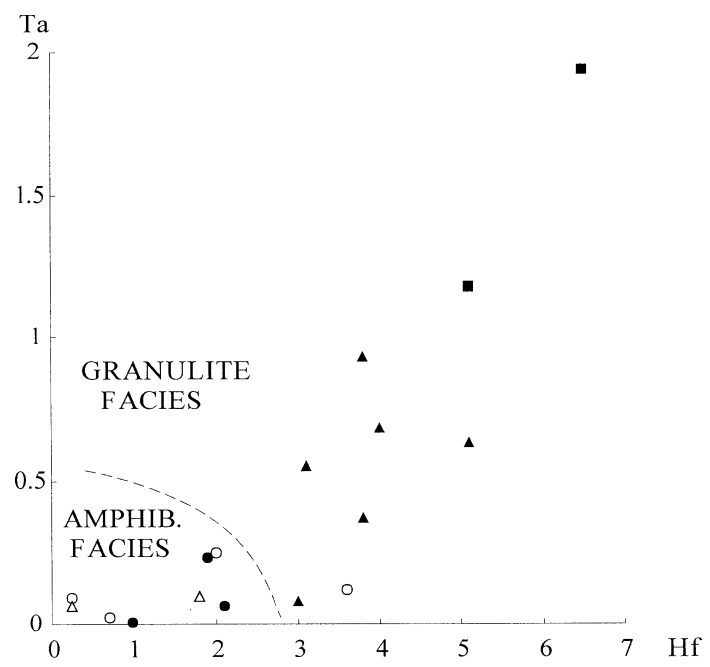

FIG. 3. Ta (ppm weight) versus $\mathrm{Hf}$ (ppm weight) in amphiboles. 
Abundance and pattern of distribution of the REE in amphiboles

The abundance of the REE in amphiboles unambiguously depends on metamorphic grade (Table 1). The average abundance of the $R E E$ in the granulite-facies amphiboles is $194 \mathrm{ppm}$, with the exception of retrograded amphibole from sample C-7; amphibolite-facies amphiboles contain an average of $34 \mathrm{ppm}$; the metasomatic amphiboles contain, on average, $c a .15 \mathrm{ppm}$. The abundance of $R E E$ in amphiboles thus markedly decreases with a lowering of the temperature of formation. The investigation of a zoned amphibole from the Njurundukan complex by ion microprobe has revealed the same consistent pattern within a single grain (Skublov 2001). In the core of the grain, which is brown hornblende rich in $\mathrm{Ti}$, the $R E E$ abundance is 4-5 times higher than in the rim, which is predominantly bluegreen (Fig. 4).

The abrupt decrease in total $R E E$ abundance in the metasomatic amphiboles may be due more to a modification of the mineral assemblages than to a temperature drop. Metasomatic rocks commonly are enriched in rutile, titanite, apatite and epidote, in which light and middle REE are concentrated (Sassi et al. 2000).

The amphibole groups differ in their chondrite-normalized $R E E$ patterns. Kaersutite samples exhibit a gentle negative slope from middle to heavy $R E E$, with a positive Nd anomaly (Fig. 5). The granulite-facies am-

\section{Amphibole/ Chondrite}

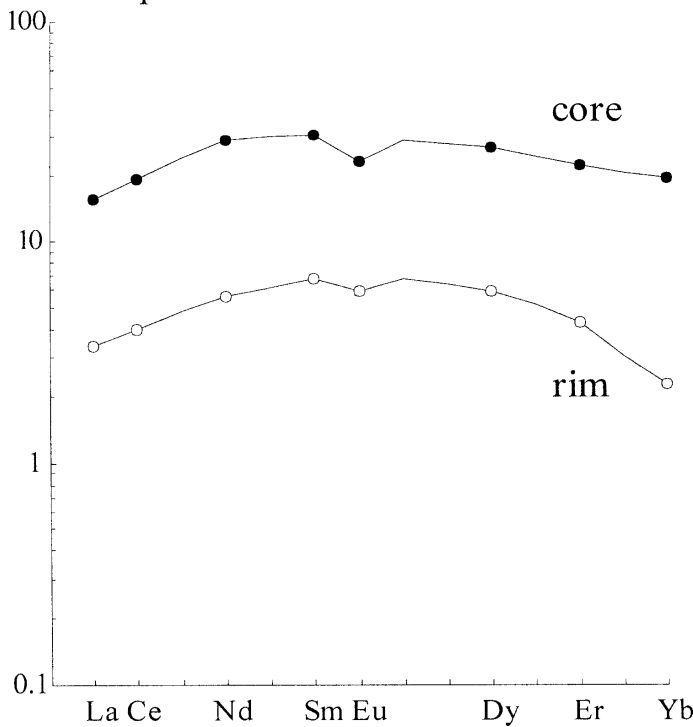

FIG. 4. Chondrite-normalized REE patterns of zoned amphibole (sample 538) from the Njurundukan complex. Chondrite-normalization factors are taken from McDonough \& Sun (1995). phiboles exhibit significant depletion in the heavy $R E E$. Patterns of $R E E$ distribution in amphiboles from the Njurundukan complex and the Lapland complex (Fig. 6) are virtually identical. Amphibole from the Sal'nye

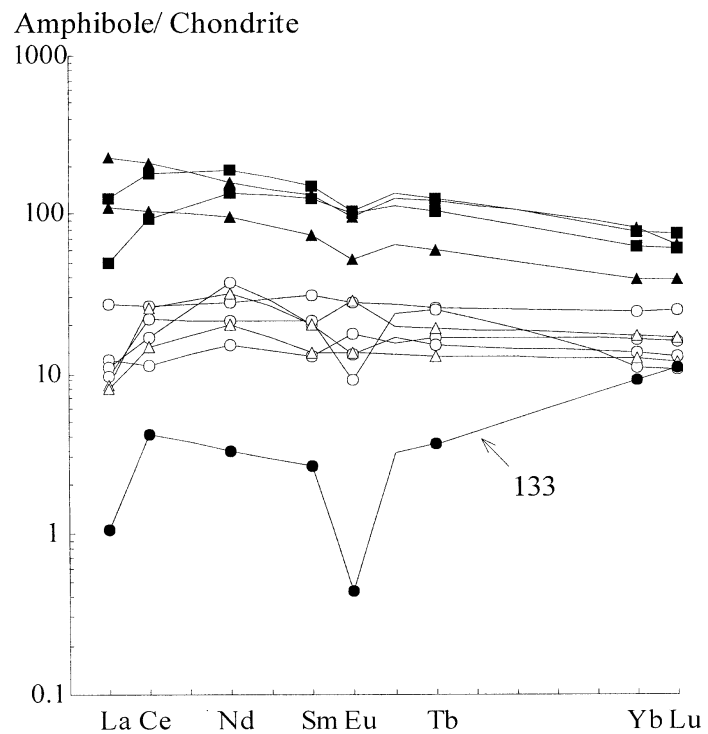

FIG. 5. Chondrite-normalized REE patterns of amphiboles from the Njurundukan complex.

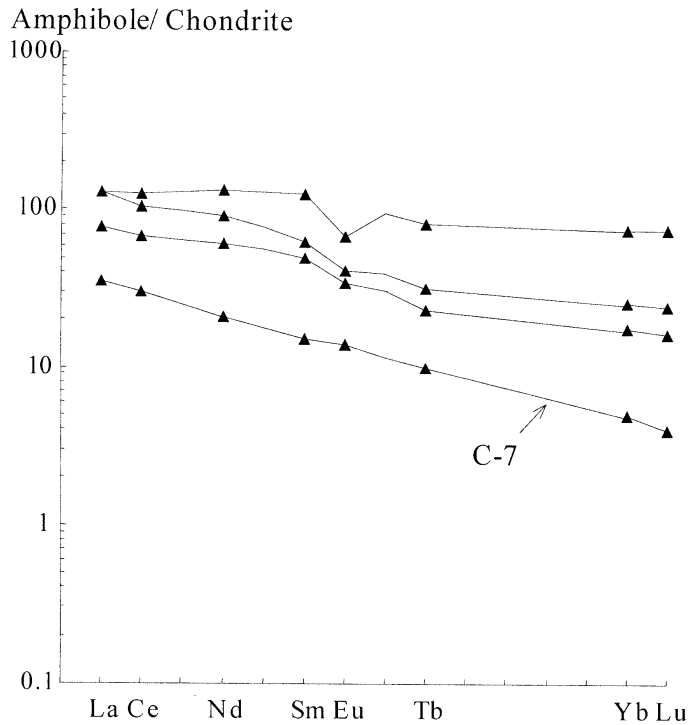

FIG. 6. Chondrite-normalized $R E E$ patterns of granulitegrade amphiboles from the Lapland complex. 
Tundry (sample C-7), which is similar to the amphibolite-facies amphiboles in its total REE abundance, shows the same heavy $R E E$-depleted distribution pattern as the unretrograted granulite-facies amphiboles.

The amphibolite-facies amphiboles from the Njurundukan complex, in contrast to the granulite-facies amphiboles, show a rather flat pattern of $R E E$ distribution, 10-40 times higher than chondrites (Fig. 5). Variations in $R E E$ of these amphiboles are shown only by the middle $R E E$. The greatest variations in $R E E$ abundances are observed in amphiboles from metasomatically altered rocks (Fig. 7): positive anomalies in Ce and negative anomalies in Sm and Eu are developed. All the metasomatic amphiboles exhibit overall similar patterns of distribution and differ only in total $R E E$ content.

Tribuzio (1992) found regular patterns of $R E E$ distribution in garnet and clinopyroxene of eclogites characterized by equilibrium assemblages of minerals. The curve of heavy $R E E$ enrichment in garnet $(\mathrm{La} / \mathrm{Yb}<1)$ intersects the curve of light $R E E$ concentration in clinopyroxene $(\mathrm{La} / \mathrm{Yb}>1)$ in the area of the middle $R E E$. The same pattern of distribution is shown by garnet and amphibole from granulite-facies mafic schist (sample 632) from Lapland (Fig. 8a).

Such a consistent pattern of $R E E$ distribution between coexisting minerals, similar to that noted in granulites, is only rarely observed in the Njurundukan complex, where the assemblage garnet + amphibole occurs in amphibolite-facies rocks (Fig. 8b). Patterns of $R E E$ distribution in the garnet-amphibole pair of sample

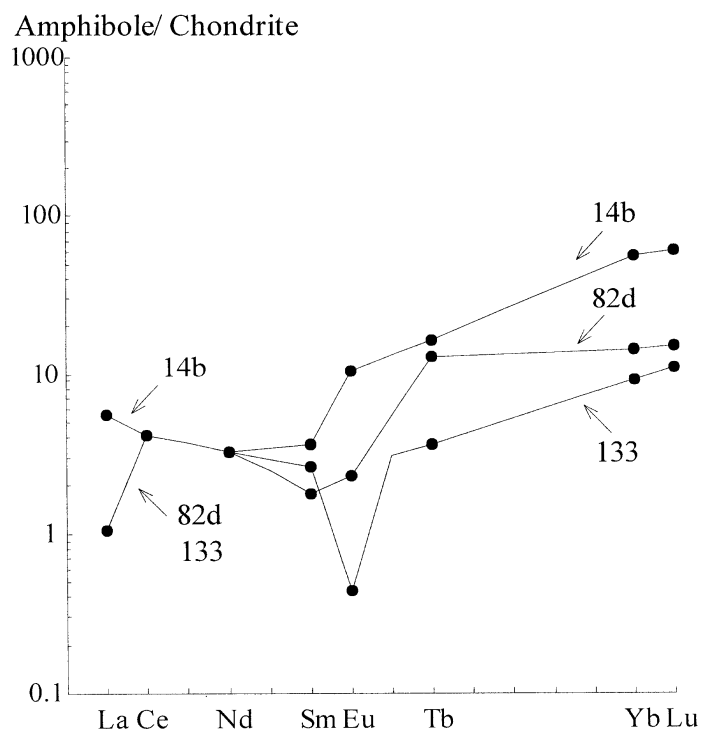

FIG. 7. Chondrite-normalized REE patterns of metasomatic amphiboles from the Njurundukan complex (sample 133) and the Belomorian complex (samples $14 \mathrm{~b}$ and $82 \mathrm{~d}$ ).
23 , in which the amphibole formed at temperatures typical of the amphibolite facies, shows a weak trend of light to heavy $R E E$ depletion, which roughly coincides with that of garnet in the range of the middle and heavy $R E E$ (Fig. 8c). Garnet occurs in this rock as large porphyroblasts with inclusions of an earlier amphibole. Anomalous distributions of the REE observed in calcic garnet from the amphibolite-facies rocks and petrographic evidence suggest the formation of garnet after amphibole (i.e., by replacement), with a pattern of REE distribution inherited from the latter. Chemical equilibrium between these two minerals is unlikely to have been attained.

The REE distribution in amphibole from the metasomatic rock (sample 133) follows that of garnet, with a pronounced Eu anomaly and enrichment in the heavy REE (Fig. 8d). Evidently, the amphibole replaced garnet, with an inherited $R E E$ distribution (Skublov 2002). A similar inherited distribution of the $R E E$ from a precursor in amphibole developed from a garnet or clinopyroxene has been found in studies of superposed metamorphism of eclogites and oceanic gabbro (Cortesogno et al. 2000, Rodriguez et al. 1999, Sassi et al. 2000).

Recurring distribution-coefficients for the trace element and $R E E$ between garnet and coexisting mineral (clinopyroxene, amphibole, biotite) for different samples from rocks similar in composition can be used as a indication of equilibrium between the two minerals (e.g., Kretz et al. 1999, Loock et al. 1990, Tribuzio 1992, Yang et al. 1999). As has been shown by Kretz et al. (1999), distribution coefficients of the rare earths between coexisting minerals are mainly thermodynamically dependent, and a close match for similar rocks suggests attainment of, or approach to, equilibrium. The greater the variations in distribution coefficients, the greater the deviations from equilibrium. Distribution coefficients for the $R E E$ between amphibole and garnet $\left(K_{D}\right)$ are close to values of the Lapland granulites (Fig. 9). Values of $K_{D}$ for granulites reveal a regular two-order reduction from light to heavy $R E E$. Such distribution coefficients for the $R E E$ have been reported for coexisting garnet and amphibole from the Scourian complex, northwestern Scotland (Pride \& Muecke 1981). Among the analyzed Laplandic samples, there is a single exception (sample $\mathrm{C}-7$ ), which has observed $K_{D}$ values for the light $R E E$ similar to those of minerals from the amphibolite facies (Fig. 9). This feature, along with a lower total REE content in amphibole (sample C-7, Table 1), suggests that a lower-temperature, disequilibrium metamorphism took place.

Distribution coefficients for the $R E E$ between amphibole and garnet for the Njurundukan complex are characterized by significant scatter (Fig. 9), suggesting considerable deviation from equilibrium in most of the amphibole-garnet pairs in amphibolite-facies rocks. It is notable that no correlation in the distribution of Sc between garnet and amphibole in the amphibolite facies 

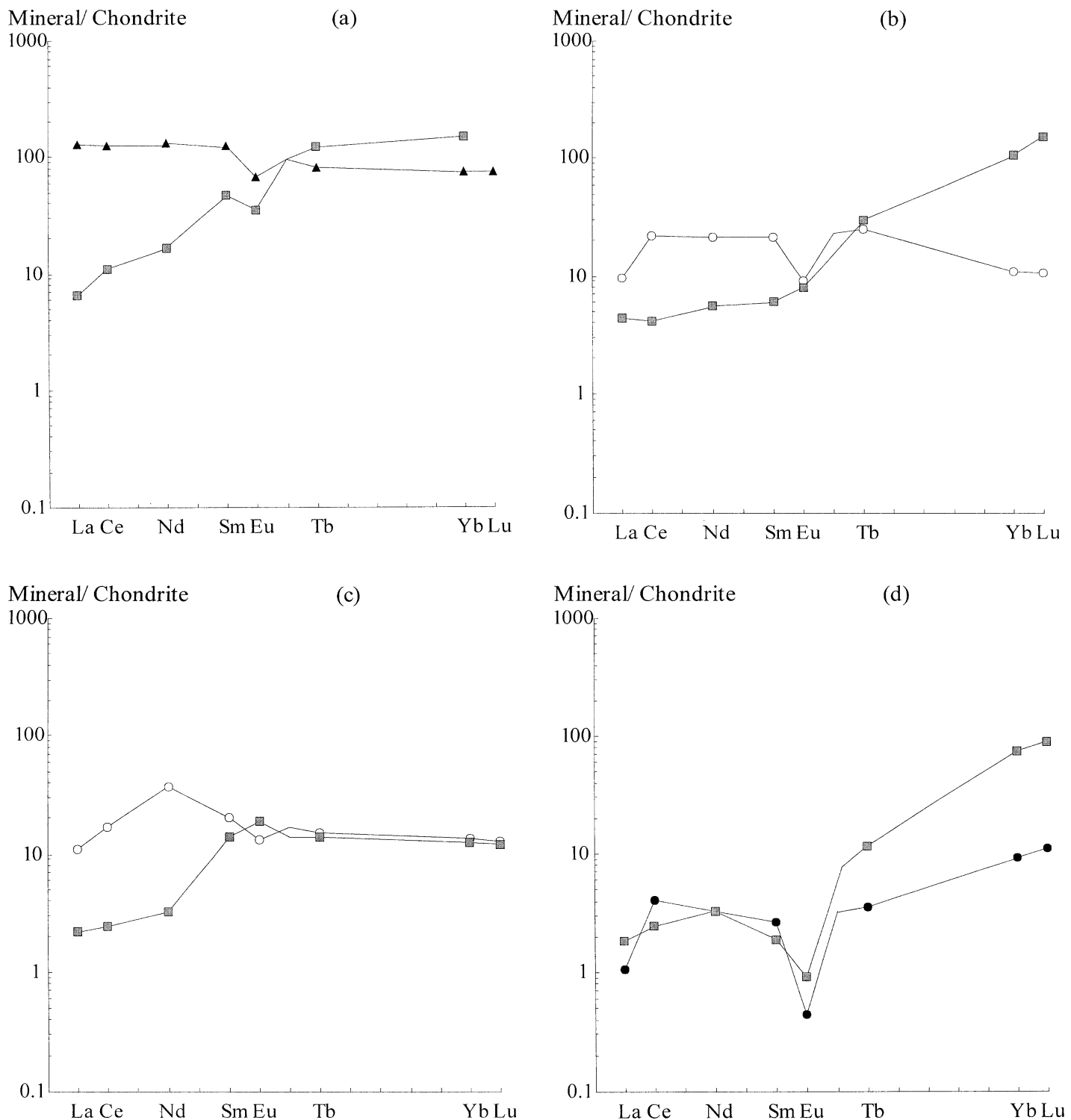

FIG. 8. Chondrite-normalized REE patterns of coexisting amphibole and garnet (black squares) from samples 632 (a), 54/3 (b), 23 (c), 133 (d).

has been found $(r=0.18)$, whereas the pattern of Sc distribution in granulites approaches the ideal $(r=0.94$, Fig. 10).

\section{DISCUSSION OF RESULTS}

As earlier established, the Njurundukan complex has been subjected to several successive episodes of metamorphism at progressively lower temperatures and at different pressures within different parts of the complex. All the episodes, from the granulite facies to low-temperature amphibolite facies, are recorded in the composition of the amphibole with respect to major and trace elements.

Kaersutite and brown hornblende from the Njurundukan granulite-facies rocks exhibit a higher Ti content and a total REE content that is 100 times that of chondrites. The distribution pattern of the REE in kaersutite 
is different from that in brown hornblende. The uncommonly high Ti content in kaersutite, coupled with occurrence of similar amphiboles in the Njurundukan dyke rocks, suggest that the kaersutite grains are relics of the igneous emplacement of the Njurundukan complex (Skublov 1993). It is pertinent to note that amphiboles from the Njurundukan granulites show a distribution and total content of $R E E$ very similar to the granulite-facies amphiboles from the Lapland complex, where pressure of the granulite-facies metamorphism was much higher than in the Njurundukan complex. It may be inferred that REE distribution and content as well as the ratio $\mathrm{La} / \mathrm{Yb}$ in amphiboles are dependent upon temperature, but not pressure of metamorphism.

Amphiboles of the second episode of metamorphism (high-temperature amphibolite facies) are characterized by a lower total REE content, 10-30 times higher than chondritic, as well as sharply lower $\mathrm{La} / \mathrm{Yb}$ value, both within the Sljudanka zone of high-pressure metamorphism and outside it. Still lower REE content marks the final episode of metamorphism. These amphibole compositions seem to reflect formation at low $\mathrm{P}-\mathrm{T}$ conditions of metamorphism. Amphiboles from episodes of amphibolite metamorphism exhibit more-or-less flat patterns of $R E E$ distribution and great variability in the range of light and middle $R E E$, with positive and negative anomalies (Fig. 5). As most significant deviations from a uniform distribution occur in metasomatic amphiboles, the distribution pattern of REE in the amphibolite-facies amphiboles are likely to reflect incipient

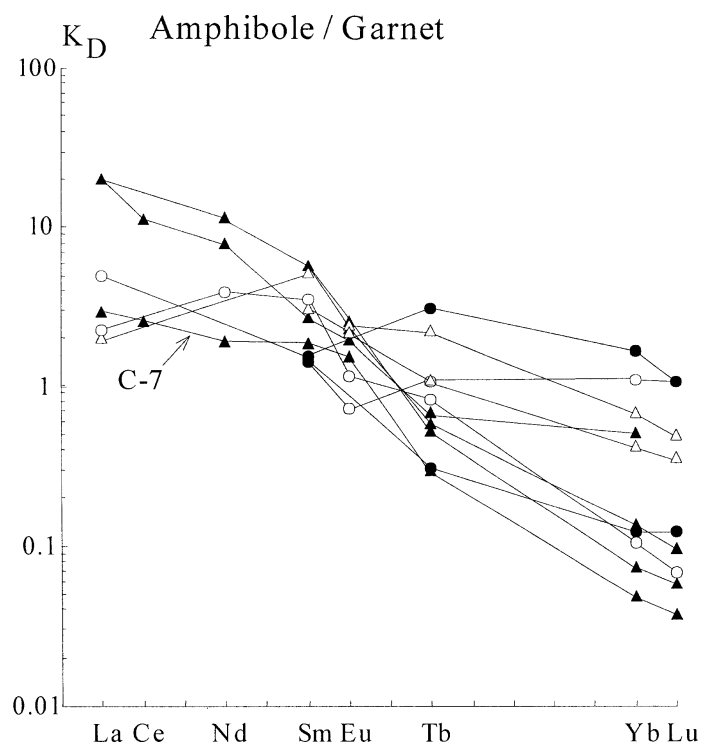

FIG. 9. REE distribution coefficients for coexisting amphibole and garnet. metasomatic transformations related to abundant fluids in shear zones.

In their investigation of the geochemistry of minerals from eclogites, Sassi et al. (2000) drew attention to the fact that changes in patterns of REE distribution in amphibole are related to those in its precursor mineral, from which the amphibole developed. Enrichment in heavy REE occurs in the case of amphibole formed at the expense of garnet. These observations are consistent with data on amphiboles from the Njurundukan complex. We have established in some cases that garnet replacing amphibole exhibits a one-to-one correspondence in REE distributions in the range of the middle and heavy REE.

Patterns of REE distribution in the metasomatic amphiboles differ markedly from those in amphiboles belonging to the main metamorphic assemblages. Data by ion microprobe confirm this finding (Skublov 2002). In addition, it is in metasomatic assemblages that amphiboles commonly show REE distributions unambiguously inherited from those of the garnet from which the amphiboles formed. Analysis of such correlations furnishes an opportunity to establish a succession of mineral formation.

The recent development of precise methods to determine small quantities of trace elements, particularly the rare earths, in minerals offers considerable scope for the petrological investigation of polymetamorphic complexes. Through a combination of techniques of REE determination in garnet-group minerals, major- and trace-element patterns are found to be useful in deciphering the metamorphic evolution of particular complexes (e.g., Hickmott et al. 1987, Hickmott \& Spear 1992, Schwandt et al. 1996).

Like garnet, amphibole-group minerals exhibit high abundances of trace elements. The wide distribution of amphibole in various rocks ranging from greenschist to

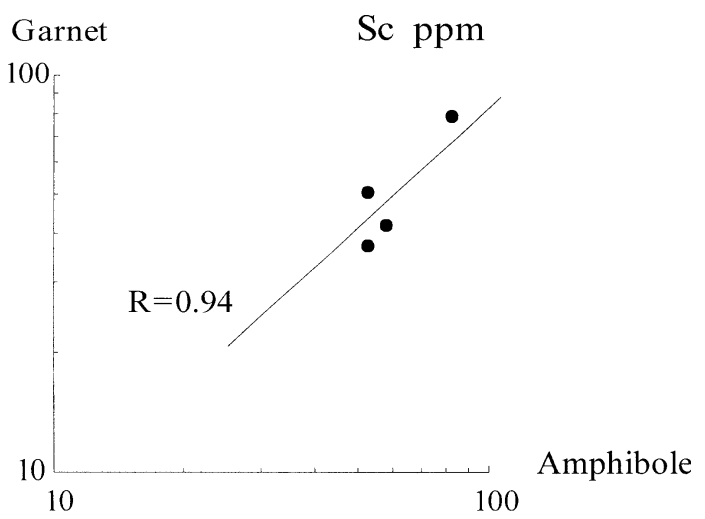

FIG. 10. Partitioning of Sc between coexisting amphibole and garnet in granulite-facies rocks. 
granulite facies makes them especially attractive in resolving the succession and nature of metamorphic processes. However, amphiboles have found but limited use in petrological modeling owing to their mineralogical and crystallochemical complexity. Reported mineral thermometers and barometers for amphibole-bearing assemblages are empirical and inconsistent with thermodynamic data (Dale et al. 2000). Experimental determinations of some REE distribution coefficients between amphibole and melt, combined with theoretical calculations, revealed disagreements with those in natural assemblages (Bottazzi et al. 1999). In addition, the $R E E$ were shown by some authors to occupy more than one crystallochemical site in amphiboles, which may be responsible for the varying mobility and ambiguous behavior of these elements in petrological processes (Bottazzi et al. 1999, Tribuzio 1992).

\section{Conclusions}

Several conclusions may be derived from a study of $R E E$ distribution in metamorphic calcic amphiboles from the Njurundukan mafic complex:

1) The total content of $R E E$ and the $\mathrm{La} / \mathrm{Yb}$ value allow discrimination between amphiboles from the granulite and amphibolite facies, regardless of pressure.

2) Metasomatic amphiboles differ from metamorphic ones in abnormally low total REE contents and $\mathrm{La} /$ $\mathrm{Yb}$ values, and in anomalous and inconsistent $R E E$ patterns.

3) Comparison of REE patterns in amphiboles and coexisting minerals, especially in garnet, reveals a succession of mineral-growth episodes due to the capacity of the secondary minerals to inherit the REE content and distribution pattern from the earlier, primary mineral.

4) Equilibrium in trace- and rare-earth-element distribution in minerals is best attained in the high-temperature granulite facies, as evidenced by similar distribution-coefficients for mineral pairs from compositionally similar rocks. In regimes of lower-temperature retrograde metamorphism and shearing, equilibrium is rarely attained, owing to the relatively higher rate of superimposed processes, the high permeability of such zones to metamorphic fluids, and differential mobility of the REE.

\section{ACKNOWLEDGEMENTS}

The authors thank N.Ye. Kozlov and A.V. Krotov for providing the samples. Reviews by T. Frisch and P. Yang greatly improved the final version of this manuscript. R.F. Martin is thanked for his editorial handling of this manuscript.

\section{REFERENCES}

Amelin, Yu.V., Rytsk, Ye.Yu., KRYMSKy, R.Sh., NeYMark, L.A. \& SkUBLOV, S.G. (2000): Vend age of enderbites from the granulite complex of the Baikal-Muisky ophiolite belt (North Baikal region): $\mathrm{U}-\mathrm{Pb}$ and $\mathrm{Sm}-\mathrm{Nd}$ isotopic evidence. Dokl. Acad. Sci. 371, 652-654 (in Russ.).

Bottazzi, P., Tiepolo, M., Vannucci, R., Zanetti, A., Brumm, R., Foley, S.F. \& OberTi, R. (1999): Distinct site preferences for heavy and light REE in amphibole and the prediction of ${ }^{\mathrm{Amph} / \mathrm{L}} \mathrm{D}_{\mathrm{REE}}$. Contrib. Mineral. Petrol. 137, 36-45.

Cortesogno, L., Gaggero, L. \& Zanetti, A. (2000): Rare earth and trace elements in igneous and high-temperature metamorphic minerals of oceanic gabbros (MARK area, MidAtlantic Ridge). Contrib. Mineral. Petrol. 139, 373-393.

Dale, J., Holland, T. \& Powell, R. (2000): Hornblende garnet - plagioclase thermobarometry: a natural assemblage calibration of the thermodynamics of hornblende. Contrib. Mineral. Petrol. 140, 353-362.

Drugova, G.M., Skublov, S.G., Astafiev, B.Yu., ShcheGlova, T.P., Savelieva, T.E. \& KRYlov, I.N. (1998): Peculiarities of the trace elements distribution within calcium amphiboles of Precambrian metamorphic rocks. Zap. Vser. Mineral. Obshchest. 127(5), 91-104 (in Russ.).

ERNST, W.G. \& LIU, J. (1998): Experimental phase-equilibrium study of Al- and Ti-contents of calcic amphibole in MORB - a semiquantitative thermobarometer. Am. Mineral. 83, 952-969.

Hickmott, D.D., Shimizu, N., Spear, F.S. \& Selverstone, J. (1987): Trace-element zoning in a metamorphic garnet. Geology 15, 573-576.

\& SPEAR, F.S. (1992): Major- and trace-element zoning in garnets from calcareous pelites in the NW Shelburne Falls quadrangle, Massachusetts: garnet growth histories in retrograded rocks. J. Petrol. 33, 965-1005.

Kretz, R., Campbell, J.L., Hoffman, E.L., Hartree, R. \& TeEsdale, W.J. (1999): Approaches to equilibrium in the distribution of trace elements among the principal minerals in a high-grade metamorphic terrane. J. Metam. Geol. 17, 41-59.

LEAKE, B.E. and 21 others (1997): Nomenclature of amphiboles: report of the Subcommittee on Amphiboles of the International Mineralogical Association, Commission on New Minerals and Mineral Names. Can. Mineral. 35, 219246.

Loock, G., Stosch, H.-G. \& Seck, H.A. (1990): Granulite facies lower crustal xenoliths from the Eifel, West Germany: petrological and geochemical aspects. Contrib. Mineral. Petrol. 105, 25-41.

McDonough, W.F. \& Sun, S.-S. (1995): The composition of the Earth. Chem. Geol. 120, 223-253.

Perchuk, L.L., Krotov, A.V. \& Gerya, T.V. (1999): Petrology of amphibolites of the Tanaelv Belt and granulites of the Lapland complex. Petrology 7, 539-563. 
Pride, C. \& Muecke, G.K. (1981): Rare earth element distributions among coexisting granulite facies minerals, Scourian complex, NW Scotland. Contrib. Mineral. Petrol. 76, 463-471.

Rodriguez, J., TribuZio, R., IbARguchi, J.I.G., Messiga, B. \& REBAY, G. (1999): Origin and trace element composition of poikiloblastic $\mathrm{Na}-\mathrm{Ca}$ amphibole in continental eclogites (Malpica-Tui, NW Spain). J. Conf. Abstr. 4, 705 (abstr.).

Sassi, R., Harte, B., Carswell, D.A. \& Yujing H. (2000): Trace element distribution in Central Dabie eclogites. Contrib. Mineral. Petrol. 139, 298-315.

Schwandt, C.S., PAPIKe, J.J. \& Shearer, C. K. (1996): Traceelement zoning in pelitic garnet of the Black Hills, South Dakota. Am. Mineral. 81, 1195-1207.

Skublov, S.G. (1993): Typochemism of amphiboles from Njurundukansky complex (North-West Baikal region). Zap. Vser. Mineral. Obshchest. 122(6), 82-88 (in Russ.).

(2001): Trace element zoning in metamorphic minerals. Mineral. Rec. 32, 43 (abstr.).

(2002): REE pattern of amphibole replacing garnet. Twelfth Goldschmidt Conf. Abstr., A271.

Drugova, G.M., VRevsky, A.B., Kozlov N.E. \& PORITSKAYA, L.G. (2000): The trace element distribution in garnets from the Lapland Granulite Belt (Baltic Shield). Bull. St. Petersburg Univ. (Pt. 7), 2, 24-34 (in Russ.).
Smirnov, V.K., Sobolev, A.V., Batanova, V.G., Portnyagin, M.V., Simakin, S.G. \& Potapov, Ye.V. (1995): Quantitative SIMS analysis of melt inclusions and host minerals for trace elements and $\mathrm{H}_{2} \mathrm{O}$. Trans. Am. Geophys. Union (Eos) 76(17), S270 (abstr.).

SORENSEN, S.S. \& GRoSSMAN, J.N. (1989): Enrichment of trace elements in garnet amphibolites from a paleo-subduction zone: Catalina Schist, southern California. Geochim. Cosmochim. Acta 53, 3155-3177.

TRIBUZIO, R. (1992): Distribution of rare earth and trace elements in the main mineral phases of the meta-Fe-gabbros from Ligurian ophiolites: crystal-chemical controls and petrogenetic implications. Plinius 7, 115-120.

YANG, PANSEOK, RIVERS, T. \& JACKSON, S. (1999): Crystalchemical and thermal controls on trace-element partitioning between coexisting garnet and biotite in metamorphic rocks from western Labrador. Can. Mineral. 37, 443-468.

Zanetti, A., Vannucci, R., Oberti, R. \& Dobosi, G. (1995): Trace-element composition and crystal-chemistry of mantle amphiboles from the Carpatho-Pannonian Region. Acta Vulcanol. 7, 265-276.

Received March 11, 2002, revised manuscript accepted January 24, 2003. 